\title{
HYPOPHOSPHATASIA: A GENETIC STUDY
}

BY

\author{
J. C. RATHBUN, J. W. MACDONALD, H. M. C. ROBINSON and J. M. WANKLIN \\ From the Departments of Paediatrics, and Psychiatry and Preventive Medicine, University of Western Ontario, \\ and the Paediatric Research Laboratory, War Memorial Children's Hospital, London, Canada
}

(RECEIVED FOR PUBLICATION MARCH 17, 1961)

Since hypophosphatasia was first described (Rathbun, 1948), other cases which have been recognized have raised the possibility that this defect of alkaline phosphatase is an inherited inborn error of metabolism. Schneider and Corcoran (1950) first suggested that this was an inherited disorder when two cases were found in one family, and this was corroborated by Sobel, Clark, Fox and Robinow (1953). McCance, Fairweather, Barrett and Morrison (1956) demonstrated reduced levels of serum alkaline phosphatase in three generations of one family, suggesting that this was a recessively inherited disorder in which the heterozygous state could be demonstrated by measuring the serum alkaline phosphatase or the phosphoethanolamine in the urine of carriers of the trait. Fraser (1957) then reviewed the literature and pointed out that $26 \%$ of reported siblings were affected: the expected incidence of a recessive characteristic. Kretchmer, Stone and Bauer (1958) tried unsuccessfully to identify heterozygous carriers by studies of alkaline phosphatase in leucocytes. Most recently, Harris and Robson (1959) have reported a study of 381 relatives of known cases by urinary chromatograms for phosphoethanolamine, demonstrating a manifestation rate of 0.58 with this method. Because of the importance in genetic counselling, it was felt worthwhile to study the family of two cases which have been under observation since 1954 and reported, in part, by Rathbun (1959).

The aim of the study was to determine, if possible, the definitive level of serum alkaline phosphatase indicative of the carrier state and the incidence of the carrier state in 30 relatives in three generations.

\section{Material and Method}

Serum alkaline phosphatase was measured using a modification of the method of Taussky and Shorr (1953).

Reagents. The following reagents were used:

Alkaline Phosphatase Substrate. $2 \cdot 5 \mathrm{~g}$. sodium glycerophosphate (beta); $2 \cdot 12$ g. sodium diethylbarbiturate.
Dissolve and dilute to $500 \mathrm{ml}$. with distilled water. The solution is kept under toluene in the refrigerator. The $p \mathrm{H}$, when mixed with one-tenth its volume of serum, should be $8 \cdot 5$.

$35 \%$ Trichloracetic Acid Solution (wt./wt.). 35 g. TCA dissolved in $65 \mathrm{~g}$. water.

Ammonium Molybdate Solution-10\%. 50 g. of $\left(\mathrm{NH}_{4}\right)_{6} \mathrm{MO}_{7} \mathrm{O}_{24} .4 \mathrm{H}_{2} \mathrm{O}$ are weighed into a litre beaker and about $400 \mathrm{ml}$. of $10 \mathrm{~N}$ sulphuric acid are added with constant stirring to prevent caking. When completely dissolved, the solution is transferred to a $500 \mathrm{ml}$. volumetric flask and washed in quantitatively with $10 \mathrm{~N}$ sulphuric acid to $500 \mathrm{ml}$. mark.

Sulphuric Acid $10 \mathrm{~N} .278 \mathrm{ml}$. of concentrated sulphuric acid are slowly added to about $700 \mathrm{ml}$. distilled water. After cooling, the solution is further diluted to $1,000 \mathrm{ml}$.

Ferrous Sulphate-Ammonium Molybdate Reagent. This must be made up freshly before use. $10 \mathrm{ml}$. of ammonium molybdate stock solution are transferred to a $100 \mathrm{ml}$. amber volumetric flask and diluted to about $70 \mathrm{ml}$.; $5 \mathrm{~g}$. $\mathrm{FeSO}_{4} \cdot 7 \mathrm{H}_{2} \mathrm{O}$ are added and the solution is made up to volume and shaken until the crystals are dissolved.

Phosphate Stock-100 mg./100 ml. $450 \mathrm{mg} . \mathrm{KH}_{2} \mathrm{PO}_{4}$ are heated in an oven at 80 degrees centigrade for 24 hours and cooled in a desiccator over night. Of this, $438 \mathrm{mg}$. $\mathrm{KH}_{2} \mathrm{PO}_{4}$ are dissolved and diluted to $100 \mathrm{ml}$. with distilled water and kept under toluene.

Phosphate Working Reagent. $2 \mathrm{ml}$. stock solution is diluted to $100 \mathrm{ml}$. with distilled water. This keeps for one week.

Method. Start with enough tubes $(12 \times 100 \mathrm{~mm}$. $)$ to take a water blank, two phosphorus standards and four tubes for each serum sample (two of these will be for incubated and two for non-incubated serum). Into each tube measure $1 \mathrm{ml}$. substrate solution and place all the tubes in $37^{\circ} \mathrm{C}$. water bath for five minutes. To two of the tubes add $0.1 \mathrm{ml}$. serum, mix well, close with 'Parafilm' and return to the $37^{\circ} \mathrm{C}$. water bath for exactly 60 minutes. After one hour, the tubes are placed in an ice bath for five minutes, during which time $0.5 \mathrm{ml}$. of $35 \%$ TCA solution is added to each tube; mix well. The tubes are removed and placed at room temperature for five minutes, during which time $0.1 \mathrm{ml}$. water, standard phosphate working solution and serum are added, respectively, to the remaining tubes; mix well. 
All tubes are centrifuged for five minutes at 2,000 r.p.m. in groups starting with incubated serum. Supernatant $(1 \mathrm{ml}$.) from each tube is placed in $12 \times 75 \mathrm{~mm}$. cuvettes and $1 \mathrm{ml}$. ferrous sulphate ammonium molybdate reagent is added to each cuvette. Mix well. After five minutes, the cuvettes are read in the Coleman spectrophotometer at $680 \mathrm{~m} \mu$.

Blood Collection. Members of the family group and a control subject with a known normal range of serum alkaline phosphatase were tested simultaneously to eliminate false values due to technique or reagent variation. Tests were performed in groups of three family members and one control subject. Blood samples were drawn from the four subjects within a total period of about 15 minutes and the determinations were performed on the serum as soon as it was separated by centrifugation. Because serum values change if the determination is not performed at once, family members were assembled in two hospitals near their homes. For these family members in out-of-town hospitals, all the tests were performed using the same technique, equipment and reagents as in the War Memorial Children's Hospital Research Laboratory.

TABLE 1

MALE RELATIVES OF PARENTS

\begin{tabular}{|c|c|c|c|}
\hline \multicolumn{2}{|r|}{ Maternal } & \multicolumn{2}{|r|}{ Paternal } \\
\hline Name & $\begin{array}{l}\text { Alkaline Phosphatase } \\
\text { (Bodansky units) }\end{array}$ & Name & $\begin{array}{l}\text { Alkaline Phosphatase } \\
\text { (Bodansky units) }\end{array}$ \\
\hline $\begin{array}{l}\text { J.B. } \\
\text { C.B. } \\
\text { V.B. }\end{array}$ & $\begin{array}{l}1 \cdot 8 \\
3 \cdot 1 \\
3 \cdot 4\end{array}$ & $\begin{array}{l}\text { P.B. } \\
\text { Ra.B. } \\
\text { Ph.B. } \\
\text { R.B. } \\
\text { J.B. } \\
\text { Gd.B. } \\
\text { G.B. } \\
\text { Re.B. }\end{array}$ & $\begin{array}{l}1.4 \\
1.6 \\
1.6 \\
1 \cdot 9 \\
2 \cdot 2 \\
2.7 \\
3 \cdot 5 \\
3 \cdot 5\end{array}$ \\
\hline
\end{tabular}

Normal mean $2 \cdot 7 \pm 0 \cdot 58$

TABLE 2

FEMALE RELATIVES OF PARENTS

\begin{tabular}{c|c|c|c}
\hline \multicolumn{2}{|c|}{ Maternal } & \multicolumn{2}{|c}{ Paternal } \\
\cline { 1 - 2 } Name & $\begin{array}{c}\text { Alkaline Phosphatase } \\
\text { (Bodansky units) }\end{array}$ & Name & $\begin{array}{c}\text { Alkaline Phosphatase } \\
\text { (Bodansky units) }\end{array}$ \\
\cline { 1 - 2 } L.L. & 1.1 & C.R. & 1.3 \\
L.B. & 1.4 & B.B. & 1.5 \\
I.Q. & 1.7 & D.P. & 1.6 \\
B. & 1.7 & J.B. & 1.6 \\
N.V. & 1.7 & A.H. & 1.8 \\
R.L. & 2.0 & B.M. & 2.4 \\
D.M. & 2.5 & B. & 2.4 \\
B.M. & 2.6 & & \\
\hline
\end{tabular}

Normal mean $2 \cdot 4 \pm 0 \cdot 7$

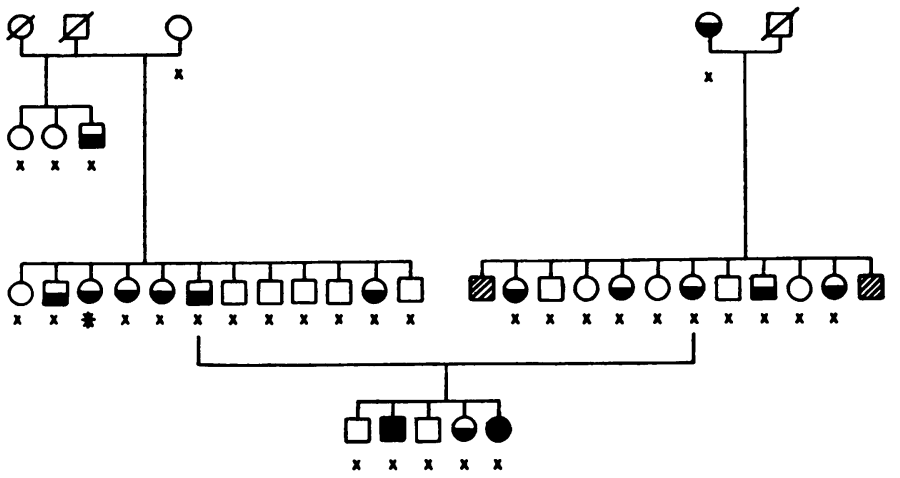

$\square$ or $\bigcirc$ UNAFFected MALE or female

$\square$ or affected male or female

$\square$ or $O$ heterozygous carriers

$\mathbb{Z}$ or NOT TESTED for aLK. PHOSPhatase

$\square$ or $\varnothing$ DECEASED - NOT TESTED

$X$ - EXAMINED PERSONALLY

* - - EXAMINED COMPETENTLY BUT NOT PERSONALLY

Fig. 1.

The supernatant fluid obtained after deproteinization was kept refrigerated overnight. The colour was then developed with ferrous sulphate ammonium molybdate reagent. Separate experiments have shown that the phosphorus values are not affected by the overnight storage. All members of the control group were apparently healthy nurses, medical students, doctors and other hospital employees. A scatter diagram revealed no trend of variation in values with age among the adult population sampled.

\section{Results}

Stern (1947) has shown that females have lower values than males and the results were therefore separated into sex groups.

Table 1 shows the results obtained in the male relatives of the known cases, while Table 2 shows the results of the female relatives.

Table 3 gives the results of the examination of the siblings and Fig. 1 illustrates the family pedigree where heterozygous carriers were considered to be all persons with levels of serum alkaline phosphatase below $2 \cdot 0$ Bodanski units, regardless of sex.

TABLE 3 SIBLINGS OF CASES

\begin{tabular}{c|c|c}
\hline & \multicolumn{2}{c}{ Siblings } \\
\cline { 2 - 3 } Name & Sex & $\begin{array}{c}\text { Alkaline Phosphatase } \\
\text { (Bodansky units) }\end{array}$ \\
\hline R. & $\mathbf{M}$ & $6 \cdot 1$ \\
R. & $\mathbf{F}$ & $3 \cdot 5$ \\
J. & M & $5 \cdot 0$ \\
\hline
\end{tabular}


TABLE 4

MEAN SERUM ALKALINE PHOSPHATASE LEVELS (BODANSKI UNITS): FAMILY MEMBERS $v s$. CONTROLS BY SEX

\begin{tabular}{c|c|c|c|c|c|c}
\hline & \multicolumn{2}{|c|}{ Family Members } & \multicolumn{3}{|c}{ Controls } \\
\cline { 2 - 7 } & No. & Mean & S.D. & No. & Mean & S.D. \\
\hline Males .. & 11 & $2 \cdot 4$ & $\pm 0 \cdot 8$ & 18 & $2 \cdot 6$ & $\pm 0 \cdot 7$ \\
Females .. & 15 & $1 \cdot 8$ & $\pm 0 \cdot 4$ & 24 & $2 \cdot 4$ & \pm 0.7 \\
\hline Total .. & 26 & $2 \cdot 1$ & - & 42 & $2 \cdot 5$ & - \\
\hline
\end{tabular}

\section{Statistical Analysis}

The control group consisted of 18 males and 24 females, and therefore equated with the family group in terms of sex ratio (Table 4).

Statistical significance $(p<0.05)$ could be attached to a reduction of 0.4 units in the overall mean value for the family group, as well as to a tendency for females generally to have lower values than males. However, a further tendency for values in the family group to be reduced more for females than for males failed to attain statistical significance.

\section{Discussion}

When these figures of the family group are compared with normal controls, not separated for sex, using analysis of variance (Snedecor, 1946) the difference is significant (Table 5). Hence it appears feasible to separate the carriers by this method. As the father (R.B.) had a level of 1.9 B.U. and the mother (B) had a level of 1.7 B.U., it is reasonable to state that the heterozygous carrier level in the male and female exists at levels at, and below, 1 S.D. of the normal mean. These figures suggest that a level below 2 Bodanski units of serum alkaline phosphatase is indicative of the heterozygous carrier state for at this level $50 \%$ of the examined aunts, uncles and parents are shown to be carriers; this is the expected incidence. This level will include, however, about $15 \%$ of normal persons owing to the overlapping of the normals with heterozygous carriers. Further careful studies may allow a more precise evaluation.

It has been our experience that the assay of serum alkaline phosphatase is plagued with many difficulties, and if the technique is not well controlled the results may be valueless. Unfortunately, in the literature, there are a wide variety of methods of determining the serum alkaline phosphatase. The results of one observer cannot be compared directly with those of another because of different methods used, even though these results are qualitatively similar. This has produced chaos in this field.

The evidence put forward by Harris and Robson
TABLE 5

ANALYSIS OF VARIANCE ON DATA IN TABLE 4

\begin{tabular}{|c|c|c|c|c|c|}
\hline Source of Variation & $\begin{array}{l}\text { Degrees } \\
\text { of } \\
\text { Freedom }\end{array}$ & $\begin{array}{c}\text { Sums } \\
\text { of } \\
\text { Squares }\end{array}$ & $\begin{array}{l}\text { Mean } \\
\text { Square }\end{array}$ & $\mathbf{F}$ & $\mathbf{P}$ \\
\hline $\begin{array}{l}\text { Experimental group } \\
\text { Sex .. } \\
\text { Groups vs. sex inter- }\end{array}$ & $\begin{array}{l}1 \\
1\end{array}$ & $\begin{array}{l}2 \cdot 96 \\
1 \cdot 92\end{array}$ & $\begin{array}{l}2 \cdot 96 \\
1 \cdot 92\end{array}$ & $\begin{array}{l}6 \cdot 58 \\
4 \cdot 27\end{array}$ & $\begin{array}{l}<0.05 \\
<0.05\end{array}$ \\
\hline $\begin{array}{rrr}\operatorname{action} & \cdots & \cdots \\
\text { Residual } & \cdots & \cdots\end{array}$ & $\begin{array}{r}1 \\
64\end{array}$ & $\begin{array}{r}0.99 \\
29 \cdot 11\end{array}$ & $\begin{array}{l}0.99 \\
0.45\end{array}$ & $2 \cdot 20$ & $>0.05$ \\
\hline Total $\ldots$ & 67 & $34 \cdot 98$ & - & 一 & 一 \\
\hline
\end{tabular}

(1959), together with the studies presented here, confirms the fact that hypophosphatasia is an inherited recessive disease in which the carrier state can be detected in most cases. The importance of this in genetic counselling needs no emphasis.

\section{Conclusions}

Hypophosphatasia is inherited as a recessive characteristic.

The carrier state is represented by adult persons with serum levels below 2 Bodanski units.

The normal level for males is $2 \cdot 7 \pm 0 \cdot 58$ Bodanski units and for females is $2 \cdot 4 \pm 0 \cdot 7$ Bodanski units.

A plea for uniformity in chemical determinations is made.

The cases studied were referred by Dr. William $L$. Wilford, Wallaceburg, Ontario. As a result of his interest and the interested co-operation of the B. family, this study became possible. Our thanks also go to the Sydenham District Hospital, Wallaceburg, and to the Hotel Dieu Hospital, Windsor, Ontario, for the use of their Laboratories.

Our appreciation is extended to Dr. E. Harpur of Montreal Children's Hospital for the determination on one of the relatives.

\section{REFERENCES}

Fraser, D. (1957). Hypophosphatasia. Amer. J. Med., 22, 730. Harris, H. and Robson, E. B. (1959). A genetical study of ethanolamine phosphate excretion in hypophosphatasia. Ann. hum. Genet., 23, 421.

Kretchmer, N., Stone, M. and Bauer, C. (1958). Hereditary enzymatic effects as illustrated by hypophosphatasia. Ann. N.Y. Acad. Sci., 75, 279.

McCance, R. A., Fairweather, D. V. I., Barrett, A. M. and Morrison, A. B. (1956). Genetic, clinical, biochemical and pathological features of hypophosphatasia. Based on the study of a family. Quart. J. Med., 25, 523 .

Rathbun, J. C. (1948). Hypophosphatasia; a new developmental anomaly. Amer. J. Dis. Child., 75, 822 .

- (1959). Hypophosphatasia. Helv. paediat. Acta, 14, 548.

Schneider, R. W. and Corcoran, A. C. (1950). Familial nephrogenic osteopathy due to excessive tubular reabsorption of inorganic phosphate: a new syndrome and a novel mode of relief. J. Lab. clin. Med., 36, 985.

Snedecor, G. W. (1946). Statistical Methods, 4th ed. The Iowa State College Press, Ames, Iowa.

Sobel, E. H., Clark, L. C., Jr., Fox. R. P. and Robinow, M. (1953). Rickets, deficiency of 'alkaline' phosphatase activity and premature loss of teeth in childhood. Pediatrics, 11, 309.

Stern, M. I. (1947). Levels of serum alkaline phosphatase among infants (2-27 months) in the British Zone of Germany. Brit. J. Nutr., 1, 182.

Taussky, H. H. and Shorr, E. (1953). A microcolorimetric method for the determination of inorganic phosphorus. J. biol. Chem., 202, 675 . 